\title{
Second Language Acquisition and Learning in Senegal, the Case of the English Language: Methods and Techniques for Developing the Speaking Skills through Communicative Activities in the Sixth Form
}

Daouda NGOM*, Mame Sémou NDIAYE

Cheikh Anta Diop University of Dakar / Senegal

DOI: $10.36348 /$ sjhss.2020.v05i06.009

| Received: 15.06.2020 | Accepted: 22.06.2020 | Published: 26.06 .2020

*Corresponding author: Daouda NGOM

\section{Abstract}

Language learning often takes a long process and can be also done in different settings or environments: in family or at school, etc. The learning of a second language consists in finding some other forms that help being able to communicate fluently. It is a matter of knowing how to restructure all the sounds (of a given language) that permit to form and distinguish words, how to combine these words so as to make meaningful sentences and how to find a new organization of the meaning by the words and the grammar. After that, the learner starts trying to speak fluently in oral or writing. The teaching of speaking at school contributes, with the help of the teacher (through the different interactional and communicative given tasks), to the building of confident of the learner to speak orally. This article tries to put up these aspects relating to the acquisition and learning English as second language for the Senegalese learners in general, particularly the ones in the sixth form and proposes a reflection on the methods and techniques, most appropriate, for the implementation of the communicative skill. Thus, after the presentation and analysis of the different data collected through questionnaires, we will cross analysis the different results in order to draw practical conclusions. Then, we will focus on results and implications, on the basis of the aftermath of our study; we will propose recommendations to each stakeholder.

Keywords: language acquisition, teaching speaking, English language, communicative skills.

Copyright @ 2020: This is an open-access article distributed under the terms of the Creative Commons Attribution license which permits unrestricted use, distribution, and reproduction in any medium for non-commercial use (NonCommercial, or CC-BY-NC) provided the original author and source are credited.

\section{INTRODUCTION}

People have always used various methods to be in communication with others. Thus, TV, computers, and mobile phones play today an important role as far as connecting people are concerned. Therefore, the spread of those means of communication often goes hand in hand with speaking, which is one the four skills taught to students in English language classroom. In addition, people use it in their professional or educational lives. Some use this skill in order to call people whereas others, particularly students use speaking to do their exposés, their homework for instant when they rehearse a drama, debate for example when they have a competition or just to have a good grade on the exam day. Then speaking has become a challenge to be faced owing to its importance in everyday life. In a world that depends so much on information and data people should not only write well, but also speak well and very fluently. All organizations and institutions need people who can present information and ideas very clearly. The invention of the media, mobile phones and computers reinforces our desire to communicate orally. It is not then surprising to see English language teachers doing their utmost to help learners improve their speaking skills. They always try to make the students understand that the speaking skills are not limited to school but as a tool they will need in real life. Unfortunately, speaking which should be of great benefit to people, especially to students, is neglected. Too much time is devoted to the teaching of the other three skills (reading, writing and listening) at the expense of speaking. In junior and particularly senior secondary school, students are hardly taught how to do a presentation or how to introduce one, be it a dialog, an interview in a communicative approach. Besides, speaking compared to the other skills, of which students need to be familiar with today, is relegated a position of secondary importance.

However the situation is not so desperate. The role of English teachers in such a field is to develop the speaking skill. This means motivating the learners 
through communicative activities without which students will be always confronted with problems. Even though the three to six hours in class exposure allotted to the learning of English is insufficient, teachers should manage to devote enough time and energy to the teaching of productive language skills with an emphasis on speaking. Most EFL teachers tend to give precedence to reading comprehension and vocabulary acquisition tasks over the output generating activities that are speaking and writing, just because these are said to be time consuming. This article will be structured as follows:

- The first part will be devoted to the teaching of speaking in the Senegalese context. It will successively deal with the description of the context, the identification of the problem before defining the proper objective of the research endeavor.

- As for the second part, it will consist of a literature review opening on the clarification of a certain number of concepts related to the speaking skill. It will also focus on pedagogical theories and practical methods and strategies related to the teaching of speaking.

- The third part will be about the proposal of theoretical and practical solutions in the form of various communicative activities designed to serve as concrete practical examples

- The fourth part will display the work methodology adopted to achieve the research paper. After the presentation and analysis of the different data collected through questionnaires, we will cross analysis the different results in order to draw practical conclusions.

- Then, the fifth part will focus on results and implications, on the basis of the aftermath of our study; we will propose recommendations to each stakeholder.

\section{Problematic and justification of the context}

Senegal, like many other countries in Africa, has been colonized by France. That colonial power has consequently influenced our country in many ways. In fact French has become not only the official language but also the medium of instruction. Therefore, almost all the school subjects are taught in French except in some bilingual private school where both English and French are used. The Senegalese students are in contact with the French language at a very early age when they are nearly six or seven years old. And this will be so up to university.

As for English as a foreign language, Senegalese students are in contact with it just after the end of elementary school at the age of 12 or 13 . Nevertheless, the Senegalese authorities being aware of the importance of the English language, they find it necessary to introduce the teaching of that language in the national syllabus. For this particular reason, English has been introduced in the curriculum as early as the creation of the first secondary school as a foreign language. In fact, the Senegalese students are given the opportunity to discover and learn just after the elementary school.

When in the sixth form, Senegalese learners have studied English grammar and vocabulary, the skills attached to the language such as speaking, writing, listening and reading. These skills are differently developed in students across the school levels. In the same vein, we notice that Senegalese classes are overcrowded; the classes in general count at 60 students depending on the streams and this is problematic when we deal with teaching in general and speaking in particular. In fact the L (literacy) stream gathers more students than the others ( $\mathrm{S}$ : scientific, $\mathrm{T}$ : technical). The time allotted to English varies according the forms, from at least 3 to 6 hours a week. It is worth mentioning that English teaching and learning have gained more importance in the education system as the English language becomes one of the main subjects in Senegal so that it appears in the entire curriculum, from the end of the elementary to the advanced levels. Even for those who wish to further their studies in English they can either go to Cheikh Anta Diop or Gaston Berger universities among others? Both are respectively located in Dakar and Saint-Louis (Senegal). Even vocational schools include it in their students' learning program. Over the last few years many methods have been experimented for the teaching and learning of the English language. These methods range from the grammar translation approach to the current communicative approach. The latter is thought to be more adequate and appropriate to help learners use the language receptively (reading and listening) and productively (speaking and writing). In Senegal, the focus is on communicative language teaching for two mean reasons: First, research findings [1] have proved that (CLT) is an effective approach to develop communicative competence. Second, the Senegalese syllabus recommends teachers to develop communicative competence through communicative approach. The advocates of this method believe that language should be taught as and for communication. After having completed four years of study, students are tested in a national exam in Reading and Writing and in an oral interview. But even if some of these students at the end have a relatively command of English, the results are still unsatisfactory as far as Speaking is concerned, so teachers in pedagogic cells and trainees in research address the issue of developing oral skills. There are still countless problems related to the teaching/learning process but we will just identify in the next step some problems that have bearing on our topic meaning the teaching of the Speaking in the sixth form. In that form teachers have got between 2 and 5 hours per week devoted to the English language teaching, depending on the on the streams. 


\section{Identification of the problem}

From my learning and teaching experience, I discover that the ability that students covet most is speaking the language fluently. How many times haven't we heard our students say that they understand, but they do not feel confident in using the language in classroom oral activities? Though they have got some knowledge of its grammar and its vocabulary, our students are still incapable of expressing themselves orally in good English after at least four or five years in learning it. The reasons may stem from our cultural background in which people are inhibited to take floor in public. In a classroom, this reason is fostered by the fact that students do not want to lose face before their peers. They do not want their peers laugh at them when they are mistaken or make mistakes when speaking. This does not contribute to develop the speaking skill. As a result, they expect the teacher to do all the talking and the explanation, and they view themselves as listeners and not takers, reducing themselves to mere receivers of the language.

\section{OBJECTIVES}

As stated above teacher and learners face many problems in the teaching/learning process of speaking skills unlike the other skills like Reading and Writing, the speaking skills are neglected in many English classrooms, particularly in the sixth form.

The purpose of this of this work is:

- to help students with oral activities to practice the language by communicating their ideas, sharing their opinions, taking turns, discussing in the entire and;

- suggest ways to the teachers for them to help students develop their conversation ability;

- to highlight, in other words, the importance of teaching speaking, but also to assess the teaching materials and see how they can be adapted, if need be.

To achieve this goal we will try to show them how to develop their oral language skills through communicative and efficient strategies that will allow students to express themselves freely and creating in an authentic and real way.

\section{LITERATURE REVIEW}

Conceptual Framework: Nature and Characteristics of speaking

What is speaking?

Almost all the specialists agree on the notion of speaking as oral communication.

"Oral communication is a two-way process between speaker and listener (or listeners), involving the productive skill of speaking and the receptive skill of understanding (or listening with understanding). Both speaker and listener have a positive function to perform: the speaker has to encode the message to be conveyed in an appropriate language, while listener (no less actively) has to decode (or interpret) the message"'[2].

According to this reflection of Byrne, speaking is an interactive process of constructing meaning that involves producing, receiving and processing information. In the same line of ideas, Roger Scott [3] in his contribution to the book "Speaking" written by [4] states:

"Oral communication is typified as an activity involving two (or more) people, in which the participants are both hearers and speakers having to react to what they hear and make their contribution at high speed. Each participant has an intention or sets of intentions-goals that he wants to achieve in the interaction"

Clearly enough, both speakers and hearers have an active role to play in the interaction. A speaker's skill and speech habits have an impact on the success of any exchange. The linguist [5] on his part makes a critical analysis of the nature of speaking. He distinguishes speaking in terms of usage and speaking in terms of use. For him speaking in terms of usage involves the manifestations either of the phonological system or the grammatical system of the language or both. In this sense, speaking is active or productive. However, speaking as an instance of use is part of reciprocal exchanges both reception and production plays a part. Speaking then involves receptive and productive participation. To make his analysis more explicit, Widdowson distinguishes the term "speaking" as the manifestation of language as usage and "talking" as the realization of the language as use.

When teaching speaking skills, the teacher has some goals that he wants to achieve. [2] states:

"The main goal in teaching the productive skill of speaking will be oral fluency; the ability to express oneself intelligibly, reasonably, accurately and without hesitation". For him, in order to communication effectively, learners need an adequate mastery of grammar and vocabulary as well as phonology and over learning in any of these areas will serve no purpose.

Speaking is different from writing. The speaker is confronted with what [6] called "time pressure". That is to say the speaker does not have much time to reflect when speaking and that is not the case for the writer.

"Time pressure" tends to affect the language used in at least two main ways. First speakers use devices in order to facilitate production and secondly they often have to compensate for the difficulties. 
Van Duzan [6] on his part draws a conclusion from this time pressure those discreets elements such as turn taking, rephrasing, simplification compensation etc.

As a result of the above mentioned reflection, we can say that some specialists focus on the nature of speaking while others focus its characteristics. In addition to some specialists' work, other researchers have dealt with the issue.

\section{Pedagogical theories and practices underlying the teaching of speaking skill}

After having explored the views of some researchers and linguists on the nature and characteristics of speaking, let's now focus on theories by pedagogues which are more likely to be useful in an ELT classroom.

Almost all of these are based on the assumption that people naturally speak in real life for a given purpose or goal. This purpose or goal can only be achieved or fulfilled thanks to speaking roles. Thus the first step towards the development of the speaking skill is to make the learner be aware of and manipulate the different types of speaking functions by accomplishing tasks such as asking for and giving information, expressing ideas, opinions or feelings, giving orders, instructions or advice...

Many attempts have been made by ELT specialists and pedagogues to classify the various speaking functions. In Teaching the Spoken Language, (Brown and Yule) distinguish between interactional functions and transactional ones. Talk as transaction refers to the use of language to get things done whereas in talk as interaction language is used for social intercourse.

In transaction, the focal point is the message and the main objective is to make oneself understood. There are cases where the emphasis is exclusively laid on what is being said or achieved. The interlocutors request or give information as in situation where one asks for or gives the date, the time or direction. There are other situations in which the speaker asks for goods or services. It is the case of people calling an emergency number or talking to their mechanics. In such situations, there is very little or no interest on the interlocutors and on the social aspect of their relation to each other. As Jones [7] puts it in transactions:

"Talk is associated with other activities. For example students may be engaged in hand on activities...in this type of activities, students and teachers usually focus on meaning or on talking their way to understand".
Talk as interaction can be lumped in with discussion and conversation. In social interaction activities, the focus is on the interlocutors rather than on the message delivered. Interactional oral communication includes situations like greetings, making friends, storytelling, conversing or discussing. It is basically characterized by the use of the conversational register, repetitions, false starts, back channeling, verbal fillers as well as the frequency of generic terms. Since most of human talk consists of social interaction exchanges. Interactional classroom activities are extremely important in the sense that they enable the learner to reuse the language acquired in class, including both linguistic and lexical competence as well as discourse and strategic ones. On this score, Brown [8], citing Rivers makes it clear that "in interaction students can use all they possess of the language, all they have learned or casually absorbed in real life exchanges".

It would however be a big mistake to consider that the distinction between interaction and transaction is clear-cut. Both types of oral communications share characteristic features and are often intertwined since mere transaction can involve social interaction. Bygate [6] is definitely right when he says that: "our learners often need to be able to speak with confidence in order to carry out many of their most basic transactions. It is the skill by which they are most frequently judged, and through which they make or lose friends."

Besides talk as transaction, there is another form of speech which is more often elaborate and formal and usually more accurate: talk as performance. Contrary to the dialogic transactional or interactional talk, talk as performance rather consists of monologues. While transactions and social interactions are made in casual, informal, consultative or intimate style, talk as performance requires most of the time the rhetorical style as in speech delivery or the deliberative style as in lectures and conferences. Jones [7], has characterized talk as performance as follows: "(It) often (has) identifiable generic structure and the language used is more predictable. Because of less contextual support, the speaker must include all necessary information in the text-hence the importance of the topic as well as textual",

A part from the triptych "talk as transaction", "talk as interaction", "talk as performance", other models and terminologies have been used by ELT specialists to classify either speaking functions or speaking activities [6], Ur [9] and [10] distinguish between task-based activities and topic-based activities. As defined by Nunan [10] a task is: "a piece of classroom work which involves learners in comprehending, manipulating, producing or interacting in the target language while their attention is focused on meaning rather than form." 
Therefore, in task-based activities, learners are brought to perform a specific task requiring, most of the time, a specific outcome or state of consensus. Taskbased activities are said to be convergent in the sense that the learners use the target language to achieve a precise goal or reach consensus. The focus is on learners' making themselves understood. Fluent communication is thus more important than accuracy. No specific linguistic feature or grammatical point is required as the learners resort to all the language they have learnt.

Task-based activities could correspond to both transactional and interactional activities. When performing a task the learner often has to give and ask for information, or give and receive directives as in transactions. Task-based activities can also correspond to social interactions in the sense that learners can use the language to mimic lifestyle social interactions as in role-plays, simulations, and problem solving and information gap activities.

On the contrary of task-based activities, topicbased activities do not promote negotiation or consensus and can have various goals or outcomes. They are thus said to be divergent. Besides, they require little or no collaboration among learners who may be performing independently to one another. The emphasis in topic-based activities is laid on the quality of the student's production. As such is resembles "talk as performance". Topic-based activities include discussion, debate and simulation. It is important for English teachers to know about the different types of speaking functions and their characteristic features. It is also extremely important that they can differentiate and classify speaking activities so as to make sure that the learners encounter and accommodate with any type of speaking situation of communication they might be involved in outside the classroom. Yet, all that knowledge on speaking functions and activities will not be of much help in their teaching practice unless they resort to appropriate and pedagogical approaches or methods implemented through effective teaching techniques and strategies.

\section{Developing Speaking: Strategies and Techniques}

Many strategies and techniques are set to help students to develop their speaking skill. These strategies and techniques have lot to do with the teacher's proficiency. In terms of developing speaking strategies and techniques, we have found three speaking areas: the mechanical area, the functional area and the social and cultural area.

- The mechanical area means speaking by using the right words in the right order with the correct pronunciation; it includes grammar, pronunciation and vocabulary.

- The functional area takes into account transaction and interaction between speakers; it shows the relation between two or many interlocutors.
- The third area, which is the social and cultural area, consists of the knowledge of the social and cultural back ground which means rules and norms of the speaking language (turn-taking, the rate of the speech, pause... These three areas allow the speaker to understand how to take into account: who is speaking to whom? In what circumstances? About what? For what reason? In communicative language teaching classes teachers should help students develop the speaking skill through these different areas by designing activities that will reflect real life situation. So learners will perform activities in specific contexts by using appropriate sentences in a correct way.

There are strategies, goals and techniques for developing the speaking skills. The communicative efficiency is one of the goals of the speaking skills. Speaking is generally making oneself understood without confusion in the message. That confusion can be due to mispronunciation, grammar, vocabulary, and the speaker's unawareness of the social and cultural background. In this case, teachers can use activities that combine language input, structures and communicative devices. In general speaking exchanges take place because there is an information or opinion gap between the speakers. So communication is reducing or eliminating that gap. For many students, the ultimate aim of learning a language is the ability to speak it, speaking is indeed a crucial part of the language learning process. Minimal responses are used to encourage the non-participant learners. Those who lack confidence in their ability to participate often keep silent when others are speaking. One way to encourage them is to help them build up a stock of minimal responses that can be used in different types of exchange. Minimal responses are predictable. Often idiomatic phrases are used to indicate understanding, agreement, doubt and other responses of a speaker. Sometimes in communication, learners have difficulties to say whether they understand their interlocutors or not. This fact exists because they are shy or they are not at ease to ask for some clarifications. So the teacher should find ways to help them overcome that problem by making them aware of that misunderstanding. Clarification can occur in any type of interaction whatever the level of the speakers. The teacher can use strategies by finding phrases for clarification and comprehension check. In these activities, learners are put in an authentic situation within the classroom. They will gain confidence in their ability to use various communicative situations that they can encounter outside the classroom. The speaking ability is generally considered as the measure of knowing a language. So the fact of knowing language is seen through fluency and accuracy. Teachers can promote fluency by doing five things in their classrooms:

- Encouraging students to go ahead and make constructive errors; 
- Creating many opportunities for students to practice;

- Creating activities that force students to practice;

- Assessing students' fluency not their accuracy;

- Talking openly to the students about fluency.

\section{Data presentation and Analysis Teachers' Questionnaire (cf appendix $n^{\circ} 1$ )}

\section{- Data Presentation}

\begin{tabular}{|c|c|c|}
\hline Questions & Numbers of answers & Percentages \\
\hline 1/ What skill do you teach the most? & & \\
\hline Writing.................................... & 07 & $35 \%$ \\
\hline Listening................................. & 00 & $00 \%$ \\
\hline Speaking..................................... & 05 & $25 \%$ \\
\hline 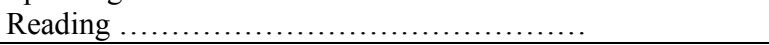 & 08 & $40 \%$ \\
\hline 2/ How often do you teach the speaking skills? & & \\
\hline Very often.................................. & 04 & $20 \%$ \\
\hline Often...................................... & 06 & $30 \%$ \\
\hline Sometimes................................... & 10 & $50 \%$ \\
\hline Rarely................................. & 00 & $00 \%$ \\
\hline 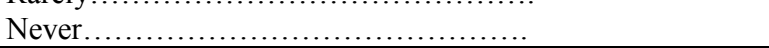 & 00 & $00 \%$ \\
\hline 3/How satisfied are you with your students' speaking skills? & & \\
\hline Very satisfied............................... & 00 & $00 \%$ \\
\hline Satisfied................................. & 08 & $40 \%$ \\
\hline Not satisfied................................ & 12 & $60 \%$ \\
\hline 4/Which of the learning modes do you use? & & \\
\hline Individual....................................... & 03 & $15 \%$ \\
\hline Pair work........................................ & 11 & $55 \%$ \\
\hline Group work................................ & 06 & $30 \%$ \\
\hline 5/What materials do you use? & & \\
\hline Audio-visual aids............................ & $03 \%$ & $15 \%$ \\
\hline Pictures......................................... & $12 \%$ & $60 \%$ \\
\hline Video cassette recorder........................ & $03 \%$ & $15 \%$ \\
\hline 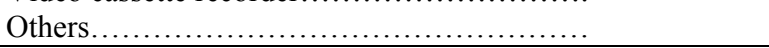 & $02 \%$ & $10 \%$ \\
\hline 6/What difficulties do your learners encounter in speaking? & & \\
\hline Lack of confidence......................... & 05 & $25 \%$ \\
\hline Fear of making mistakes........................ & 10 & $50 \%$ \\
\hline Pronunciation............................. & 05 & $25 \%$ \\
\hline 7/How do you teach the speaking skills? & & \\
\hline Games............................ & 04 & $20 \%$ \\
\hline 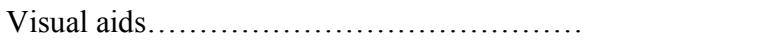 & 03 & $15 \%$ \\
\hline 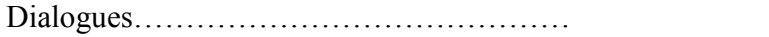 & 08 & $40 \%$ \\
\hline Debate................................. & 05 & $25 \%$ \\
\hline
\end{tabular}

In the frame of this study we distributed some questionnaires in order to find out how the speaking skill is viewed in classes in general. Both teachers and students are concerned. In this first part we are going to analyze the results of the questionnaires designed for teachers. After the collection of 20 questionnaires from the 30 we have given to teachers in the Thiaroye and Yeumbeul high schools we will present and analyze the different data of this teachers' questionnaire. So, the basis of our analysis will be on the 20 answers given by teachers to have an approximate idea of the views of some English teachers on the speaking the speaking skills. The data in this teachers' questionnaire shows that $25 \%$ of teachers we have questioned teach the speaking skills and $50 \%$ sometimes. However $60 \%$ of them are not satisfied with the students' speaking skills. The results of these three questions bring us to say that there are some problems concerning the teaching/learning process of the speaking skills. So these problems are to be detected and solutions should be found by teachers.
With the fourth questions, we see that $55 \%$ of the teachers choose pair work when teaching the speaking skills, which shows that there is interaction between students and CLT is applied by most of them. However pair work is as important as group work. We find that only $30 \%$ of teachers use activities with group work, which is not encouraging. Since group work brings more interactions between students and in this case the teacher should be a good classroom manager to involve all students. Even though it is difficult to move them and form groups in some cases that is to mean in large classes. The fifth question reveals that $60 \%$ of teachers use pictures. The use of pictures by most of them can be explained by the fact that picture are available than other materials like video cassette recorder and audio-visual aids.

In the sixth question, we noticed that the main difficulty that students face in the field of the speaking skills is the fear of making mistakes. There are $50 \%$ of teachers who have observed that problem. The rest is shared by students' lack of confidence and 
mispronunciation. There are $25 \%$ of students who don't take the floor in class because they are not confident and $25 \%$ because they don't pronounce correctly. This situation can be understood in the sense that most of the teachers do not manage their classes so as to involve every learner. In this case those who are not used to speaking in class even if they are good at writing, are anxious and shy, when they are given the floor. This anxiety reduces their capacity to think and make utterances. They are afraid of making mistakes not to be ridiculous in front of the class. So the teacher should involve the whole class by designing communicative activities that make them participate.

Concerning the seventh question with the way to teach the speaking skills, we see that $40 \%$ of teachers use dialogues when teaching speaking. Dialogues are very communicative activities which allow the students to interact so as to improve their speaking skills. But games and debates are also important and we find that only $20 \%$ of teachers use games and $25 \%$ use debates. These two ways of teaching the speaking skills are necessary because with games students can learn by doing as they are put in a situation in which they are at ease and with debates they are given the opportunity to express themselves and give their opinions.
In the questionnaire we also notice that $45 \%$ of teachers propose discussion for the success of the speaking skills because it makes all students participate, group and pair work are the modes used. As a matter of fact every learner has his word to say directly or indirectly. By indirectly we mean when working in pairs or group students give their ideas collected by the reporter of the group who will talk for them; and by directly we mean the student who reports his/her peers' ideas to the whole class. There are also $30 \%$ of teachers who propose role play which is understandable, because in such activities students are very motivated. In performing students express them as they are put in a real life situation and they interact communicatively. Only $2 \%$ propose other solutions like songs, problem solving etc.

Through this questionnaire we have seen that with the speaking skill there are some problems which should be detected and solved for the success of the teaching/learning process. Teachers should spend much more time on teaching the speaking skills as they do on reading and writing. They should design communicative activities to involve all students.

\section{Students' questionnaire (cf appendix n`2)}

\section{- Data Presentation}

\begin{tabular}{|c|c|c|}
\hline questions & Numbers of answers & Percentages \\
\hline 1/Which of the following skills do you prefer? & & \\
\hline 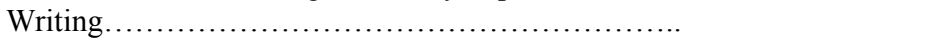 & 08 & $40 \%$ \\
\hline 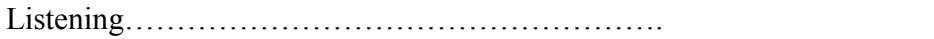 & 02 & $10 \%$ \\
\hline 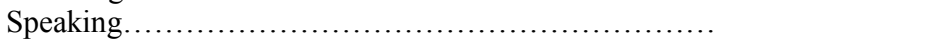 & 06 & $30 \%$ \\
\hline 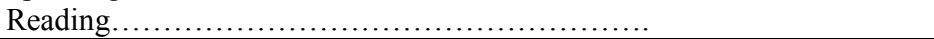 & 04 & $20 \%$ \\
\hline 2/Do you speak English in class? & & \\
\hline 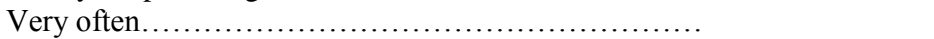 & 00 & $00 \%$ \\
\hline 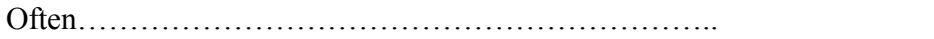 & 04 & $20 \%$ \\
\hline 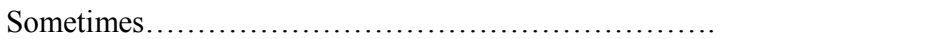 & 08 & $40 \%$ \\
\hline 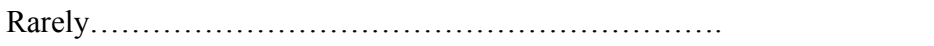 & 04 & $20 \%$ \\
\hline Never $\ldots \ldots \ldots \ldots \ldots \ldots \ldots \ldots \ldots \ldots \ldots \ldots \ldots \ldots \ldots \ldots \ldots \ldots$ & 04 & $20 \%$ \\
\hline 3/Among the following learning modes which one do you like more? & & \\
\hline Individual $\ldots \ldots \ldots \ldots \ldots \ldots \ldots \ldots \ldots \ldots \ldots \ldots \ldots \ldots \ldots$ & 08 & $40 \%$ \\
\hline Pair work............................................ & 06 & $30 \%$ \\
\hline 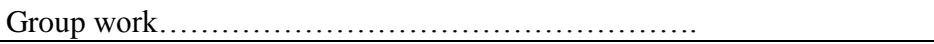 & 06 & $30 \%$ \\
\hline 4/What are your difficulties in speaking? & & \\
\hline 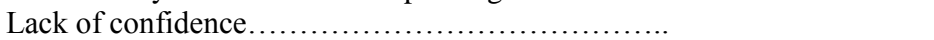 & 06 & $30 \%$ \\
\hline Afraid of making mistakes........................... & 06 & $30 \%$ \\
\hline 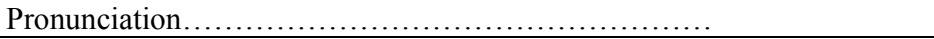 & 08 & $40 \%$ \\
\hline 5/What method used by your teacher do you like the most? & & \\
\hline Games........................................... & 00 & $00 \%$ \\
\hline Pictures........................................... & 02 & $10 \%$ \\
\hline Dialogues...................................... & 10 & $50 \%$ \\
\hline 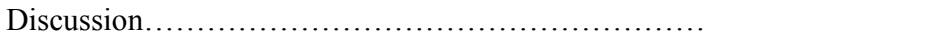 & 08 & $40 \%$ \\
\hline 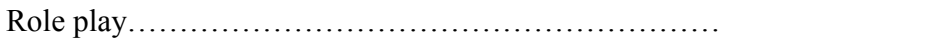 & 00 & $00 \%$ \\
\hline 6/Do you use a dictionary to check pronunciation? & & \\
\hline Yes............................................. & 08 & $40 \%$ \\
\hline 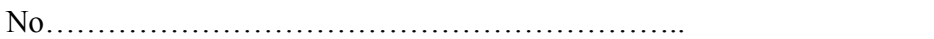 & 12 & $60 \%$ \\
\hline 7/Outside the classroom what do you do to develop your oral expression? & & \\
\hline 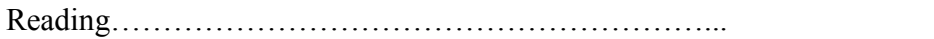 & 09 & $45 \%$ \\
\hline Join the English club................................ & 07 & $35 \%$ \\
\hline 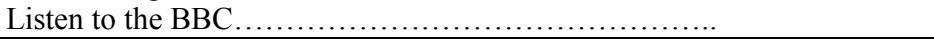 & 04 & $20 \%$ \\
\hline
\end{tabular}


After the collection of 20 questionnaires from the 30 we have given to students in Thiaroye and Yeumbeul high schools we will present and analyze the different data of these students' questionnaire. After going deep down through this questionnaire we notice that speaking is the second skill preferred by students, it comes after writing and represents $30 \%$. This result shows that even if the speaking skill is not taken into account. Teachers should propose more activities to improve learners' oral expression as it is suggested in the syllabus.

What we also observe is that among the 20 students we have questioned, none of them participates orally very often. There is only $40 \%$ who participates sometimes which shows the problem of learners' involvement in speaking activities. Some activities based on discussion, dialogue, role play, or games should be designed by teachers for group or pair work with some strategies to involve the whole class. This question is related to the following as learning mode results learners' involvement. As a matter of the fact $40 \%$ of students prefer to work individual which explains the weak result of the number of students who participate orally in class, because pair work and group work are very important for the involvement of the learners. They allow them to interact and to exchange which can improve their speaking skills.

The answers of the fourth question give an idea about the reason why most learners don't participate orally in class. All the students questioned have difficulties when speaking English. There are 40\% of them who don't speak English in class because they have problems of pronunciation, $30 \%$ are afraid of making mistakes and $30 \%$ lack confidence. This can be explained by the fact that first, as L2 English is only spoken in class for academic purposes and second, pronunciation in English is very different from pronunciation in French which is the L1 in Senegal and taught since primary school. So learners are not at ease when speaking English because they don't want to be laughed at by their peers when they make mistakes. As a consequence they prefer to keep quiet so as not to be ridiculous. Teachers should design activities based on dialogues which represent $50 \%$ and on discussion $40 \%$ of the method used by teachers to teach the speaking skills. These methods are chosen by learners to improve their speaking skills; they will be in a position of obligation and exposed to the language as in real life situation.

The sixth question raises the problem of checking pronunciation in a dictionary. It reveals that $60 \%$ of students questioned don't use the dictionary to check how words are pronounced with the phonetic transcription. As we have seen before, pronunciation is very important in English, thus the fact of not checking it, will bring many problems to learners because in English two words may look the same but with the pronunciation and the articulation they differ. Therefore teachers should give learners some methods through activities like checking pronunciation to learn how to pronounce words. They should let them know that pronunciation is very significant part of the language because through it people can know whether you master the language or not. This is the reason why other activities outside the class are necessary to develop the speaking skills. By asking the students about the outside classroom activities, we notice that $45 \%$ of them read to improve their English but their problem is that they don't have enough English documents and books in school libraries. There is only $35 \%$ who join the English clubs, which is to be improved by creating activities which draw learners' attention and interest. In English clubs the learners are among themselves and there should be no complex or lack confident to speak because here everyone can give and receive, there is a kind of exchange.

The students' questionnaire confirms the problems of the speaking skills raised since the beginning of this work. Most of the learners like writing because it is private and only the teacher can see their weaknesses. This is quite different from speaking which is expressing one's ideas, opinions.... and which shows one's personality. So, most of the learners don't like taking the floor in class, because they have some difficulties related to making mistakes and pronunciation. They like activities with dialogues and discussions but teachers don't lay emphasis on them because most of the time they use writing instead of speaking. This situation can be explained all the more so as most of the time writing is used for testing and for exams. The other problem we have seen is that a weak number of students listen to the BBC. Teachers should advise learners to listen to any radio and watch any TV where English is spoken to learn pronunciation, discover new vocabulary items and be familiar with the language.

\section{Cross Analysis of Teachers' and Students' results}

After having analyzed the two questionnaires and their results we can say that most of the teachers (40\%) do the reading skills in class. The speaking skill is taught only by $25 \%$. This result compared with the students' preference of writing $(40 \%)$ indicates that reading and writing are the skills on which teachers focus more in class. Moreover we notice in both questionnaires that most of the learners $(50 \%)$, because of the teachers' non implication in the speaking skills, do not participate frequently in speaking activities. There two causes of this problem: teachers do not involve them in communicative activities and they are shy, they are afraid of making mistakes when they are given the floor.

We also see that $60 \%$ of teachers are not satisfied with their students' speaking skills, even though pair work and group work is the teachers' most 
used learning modes $80 \%$ and the most preferred by learners $(60 \%)$. We have another remark which is that $40 \%$ of teachers teach the speaking skills through dialogues, $50 \%$ of students like dialogues and $40 \%$ like discussion. In this case there should be no problem for teachers to design activities based on dialogues and discussions to improve the learners' speaking skills.

When $50 \%$ of teachers questioned say that students don't speak in class because they fear to make mistakes, $40 \%$ of students talk about a problem of pronunciation. It is important to underline the fact that mispronunciation is part of making mistakes. Mispronouncing a word can mislead a listener. So as suggested by most of the teachers, role plays and discussions through communicative activities in class and mainly in English clubs can help learners improve their oral expressions. We see that only $35 \%$ of students join the English clubs which is not encouraging because that most of the people who master English today joined an English club in high school or at the university in the past. As a consequence we can say that if there are some problems in developing the speaking skill, it is because teachers do not take the matter seriously as with the writing or the reading skills. In addition to that students encounter many difficulties in oral communication because of the obstacles from the L1.

\section{RECOMMENDATIONS}

The results of this inquiry are not bad at all. They are more or less amazing. However some weaknesses have been found out. Indeed when employing role-plays, debates, topic discussions, we have noticed that some students are often timid in expressing their viewpoints. This seems due to a number of reasons:

- Students don't have an opinion on the subject

- Students have an opinion, but are worried about what the other students might say or think.

- Students have an opinion, but don't feel they can say exactly what they mean.

- Teachers are reluctant to implement and develop the speaking skill in class.

- Teachers think that teaching the speaking in an EFL context such as Senegal is not an easy task. For them, it is very demanding and time consuming activity. While practicing speaking in large classes, there is much noise and students are not very often enough concentrated on the focused activity. This lack of concentration transforms the course into a chat.

The observation and study we have made to find out why and how to develop the speaking skill in the advanced classes (sixth form to be more specific) have revealed the imperious necessity to improve its teaching/learning process in Senegalese schools. To do so and reach those goals of developing the speaking skill in English, efforts have to be made and actions should be undertaken at three levels:

\section{At English Teachers' level}

A CLT practitioner needs to teach all skills, we mean reading, listening, speaking and writing. English teachers are recommended to implement speaking in their classes as stated by CLT principles and the national syllabus. Therefore teachers should abide by CLT rules and constraints, its correct application and avoid falling into easiness and laziness because of the difficulties linked to teaching speaking. Through their teaching and mastery of the subject, teachers should be able to make students love English and be enough motivated to learn it. For this to happen, teachers also should create a pleasant and relaxed or free stress environment where students enjoy learning because teaching must be fun too. In such an atmosphere, teaching and learning become less tiresome and more attractive for teachers and learners as well.

In addition to the good teaching/learning conditions the teachers should create in the classroom, they should also be able to make best choices for the interest of the learners. The teachers should choose suitable topics that meet students' needs and implement communicative strategies to involve them in finding solutions. By doing so and through commitment and making efforts, the teachers will reach the goals of developing the speaking skill.

\section{At English learners' level}

In CLT, learners are no longer empty vessels or passive subjects who must fold their hands and receive everything from the teacher but they are rather learner-centered and active participants. They are in the center of their own training. For these reasons they should be enough involved in the class and build interactional attitudes among themselves and between the teacher and students. Through pair work and group work, students should acquire behaviors like information sharing, building personal relationship, improving speaking skill etc.

It is also important that the students grasp all the significance of English in the world and in their studies. When this happens, learners will make necessary efforts to learn English but most importantly be able to speak it in their everyday life for, the first function of a language any language, is speaking.

\section{At authorities' level}

Many teachers are teaching without having a pre-service teaching training. And this can in a negative way affect the teaching process. The authorities should play a crucial function in the entire process of bringing changes in schools and creating better conditions of teaching/learning. They should first provide all teachers with a pre-service training for them to be able to do 
their job correctly and properly. Then, they should put them in better working conditions we mean building adequate infrastructures in order to solve the problem of large and plethoric classes (around 100 students), recruiting professionals in each subject, supplying materials etc. Those deeds if well undertaken by the authorities will even reduce the teachers and students' strikes and help achieving the national syllabus goals.

Therefore, authorities should not fail their mission which is to define the kind of Senegalese they aim to have in the society and the ways and means to those aims. In fact the failure of the authorities will mean the collapse of all the system because there is a strong link between authorities, teachers and students.

\section{CONCLUSION}

In the process of our study we have attempted to show through the five parts how it is difficult and important to teach/develop the speaking skill. Indeed, as an obstacle to teach speaking skill, we can mention the EFL context and the reluctance of some teachers to practice English in their classes. However, since speaking is very important in the teaching/learning process of English, authorities as well as teachers and learners must be truly committed to develop its implementation in Senegalese schools.

Therefore, further investigations should be done to enhance the learners and teachers motivation for the whole development of English. As far teachers are concerned, communicative language teaching is strongly suggested to use in their teaching practice. We have also noticed that the teaching and learning of speaking is a part of the consolidation of language acquisition. It provides tools for the improvement of the learner's capacities to master the language.

\section{REFFERENCE}

1. Pica, T., \& Doughty, C. (1985). The role of group work in classroom second language acquisition. Studies in second language acquisition, 7(2), 233-248.

2. Byrne, D. (1976). Social psychology and the study of sexual behavior. Personality and Social Psychology Bulletin, 3(1), 3-30.

3. Richards, J.C., \& Rogers. T. S. (1986). Approaches and methods in Language teaching: A description and analysis. Cambridge, UK. Cambridge University Press.

4. Morrow, K., \& Johnson, K. (Eds.). (1981). Communication in the classroom: Applications and methods for a communicative approach. Longman.

5. Widdowson, H.G. (1985). Teaching language as communication; Oxford, Oxford University Press.

6. Bygate, M. (1997). Speaking. Oxford University Press.

7. Jones, P. (1998). "Planning an oral language program”, in Pauline Jones (ed.) Talking to Learn. Melbourne.

8. Brown, D. (1994). Teaching by Principles. New Jersey. Prentice Hall Regent

9. Brumfit, C. (1989). Problems and Principles in English teaching. London, Pergammer Press.

10. Nunan, D. (1989). Designing task for the communicative classroom. Cambridge: Cambridge University Press. 